\title{
IMPLEMENTASI DISPENSASI PERKAWINAN DI BAWAH UMUR BERDASARKAN UNDANG-UNDANG NO.16 TAHUN 2019 TENTANG PERUBAHAN ATAS UNDANG-UNDANG NOMOR 1 TAHUN 1974 TENTANG PERKAWINAN (Studi Kasus di Kabupaten Kuningan)
}

\author{
Gios Adhyaksa, Anthon Fathanudien, Winayanti Nurohmahwati \\ Fakultas Hukum Universitas Kuningan, \\ Email : gios.adhyaksa@uniku.ac.id, anthonfathanudien@yahoo.co.id, \\ yantiwina1@gmail.com
}

\begin{abstract}
Abstrak
Implementasi Dispensasi Perkawinan Di Bawah Umur Berdasarkan Undang-Undang Nomor 16 Tahun 2019 Tentang Perubahan Atas Undang-Undang Nomor 1 Tahun 1974 Tentang Perkawinan. (Studi Kasus di Kabupaten Kuningan) Oleh Gios Adhyaksa, Anthon Fathanudien, Winayanti Nurohmahwati, Program Studi Ilmu Hukum Fakultas Hukum Universitas Kuningan, Kuningan, 2020.

Penulis melakukan penelitian ini dengan latar belakang untuk mengetahui bagaimana pemberian dispensasi perkawinan di bawah umur di Pengadilan Agama Kuningan Kelas IA. Tujuan penulisan Artikel dalam Jurnal ini untuk mengetahui pengaturan dispensasi perkawinan di bawah umur berdasarkan Undang-Undang Nomor 16 tahun 2019 tentang perubahan atas Undang-Undang Nomor 1 Tahun 1974 Tentang Perkawinan, untuk mengetahui bagaimana implementasi dispensasi perkawinan di bawah umur di Pengadilan Agama Kabupaten Kuningan. Metode yang digunakan dalam metode penelitian ini adalah dengan pendekatan yuridis empiris dengan menggunakan data primer, sekunder dan tersier serta alat pegumpul data yang digunakan melalui wawancara, observasi dan studi pustaka. Hasil penelitian ini adalah implementasi dispensasi yang tidak sesuai dengan pasal 7 ayat (1) Undang-Undang Nomor 16 tahun 2019 tentang perubahan atas Undang-undang Nomor 1 Tahun 1974 Tentang Perkawinan tidak sah secara hukum dan jika ingin mengajukan perkawinan maka harus melakukan permohonan dispensasi ke Pengadilan Agama. Kesimpulan dari Penelitian ini adalah pengaturan pemberian dispensasi kawin di Pengadilan Agama Kuningan Kelas 1A dapat dilakukan dengan didukung oleh pasal 7 ayat (2) UndangUndang Nomor 16 tahun 2019 tentang perubahan atas Undang-Undang Nomor 1 Tahun 1974 Tentang Perkawinan dan Kompilasi Hukum Islam.
\end{abstract}

Kata kunci : Implementasi, dispensasi, perkawinan 


\begin{abstract}
The Implementation of Underage Marriage Dispensation Based on Law Number 1 of 1974 Concerning Marriage by Gios Adhyaksa, Anthon Fathanudien, Winayanti Nuurohmahwati, Law Departement, Faculty of Law, University of Kuningan 2020.

The author conducted this research with a backround that is to find out how the provision of Underage Marriage Dispensation in Kuningan class IA Religious Court. The purposes of this paper are to determine the regulation of underage marriage dispensation based on law number 1 of 1974 concerning marriage, to find out how the implementation of underage marriage dispensation in the brass district regious court. The method used in this study is an empirical juridical approach using primary, secondary, and lertiary data collection tools used through interviews, observation and study of literature. The results of this study are the implementation of a dispensation that is not in accordance with article 7 paragraph (1) of law number 1 of 1974 concerning marriage that is not legally valid and you have to make a request for dispentation to a religious court. The conclusion of this paper is the arrangement of giving dispensation for marriage in class IA Kuningan religious court can be done by being supported by article 7 paragraph (2) of law number 1 of 1974 concerning marriage and complications of islamic law.
\end{abstract}

Keywords : implementation, Dispensation, Marriage 


\section{Pendahuluan}

Berdasarkan Ketentuan Pasal 1 ayat 3 Undang-Undang Dasar Negara Republik Indonesia Tahun 1945 menyatakan bahwa Negara Indonesia adalah Negara Hukum. Yang artinya bahwa dalam penyelenggaraan pemerintahannya, Indonesia menjalankannya berdasarkan hukum. Konsekwensi hal tersebut indonesia membuat suatu prodak hukum yaitu Undang-Undang yang diharapkan dapat mengatur seluruh lapisan Warga Negara Indonesia.

Perkawinan menurut hukum agama adalah perbuatan yang suci (sakramen, samskara), yaitu suatu perikatan antara dua pihak dalam memenuhi perintah dan anjuuran Tuhan Yang Maha Esa, agar kehidupan berkeluarga dan berumah tangga serta berkerabat tetangga berjalan dengan baik sesuai dengan ajaran agama masing-masing. ${ }^{1}$ Tujuan perkawinan dalam Islam selain untuk memenuhi kebutuhan hidup jasmani dan rohani manusia, juga sekaligus untuk membentuk keluarga dan memelihara serta meneruskan keturunan dalam menjadikan hidupnya di dunia ini, juga mencegah perzinahan, agar tercipta ketenangan dan ketentraman keluarga daan masyarakat. $^{2}$

Pasal 2 ayat 1 Undang-Undang Nomor 16 tahun 2019 tentang perubahan atas Undang-Undang Nomor 1 Tahun 1974 Tentang Perkawinan menyebutkan bahwa suatu perkawinan baru dapat dikatakan sebagai perkawinan yang sah menurut hukum apabila perkawinan itu dilakukan menurut masing-masing agama dan kepercayaannya sedangkan bahwa ayat 2 menentukan tiap-tiap perkawinan dicatat menurut peraturan perundang-undangan yang berlaku. Dan Pasal 7 ayat 1 yaitu Perkawinan hanya diizinkan bila pihak pria mencapai umur 19 (sembilan belas) tahun dan pihak wanita sudah mencapai 16

\footnotetext{
${ }^{1}$ Hilman Hadikusuma, Hukum Perkawinan Indonesia, Penerbit Mandar Maju, Bandung, 2007, hlm 10

${ }^{2}$ Mardani, Hukum Perkawinan Islam di Dunia Islam Modern, Graha Ilmu, Yogyakarta, 2011, 11.
}

(enam belas) tahun sedangkan bahwa pada ayat 2 dalam hal penyimpangan dalam ayat 1 pasal ini dapat minta dispensasi kepada Pengadilan atau pejabat lain yang diminta oleh kedua orang tua pihak wanita.

Undang-Undang Nomor 16 tahun 2019 tentang perubahan atas UndangUndang Nomor 1 Tahun 1974 Tentang Perkawinan diharapkan seluruh warga Negara Indonesia dapat melakukan pernikahan dengan mengacu pada UndangUndang tersebut, Serta Kompilasi Hukum Islam (KHI) di Indonesia Nomor. 1 Tahunn 1991 mengartikan perkawinan adalah pernikahan, yaitu akad yang sangat kuat atau miitsaqaan ghaliidhan untuk menaati perintah allah dan melaksanakan merupakan ibadah. ${ }^{3}$ Juga mempunyai tujuan yang sama mengenai arti dari perkawinan itu sendiri yakni bahwa pernikahan mempunyai tujuan yang mulia dalam melestarikan dan menjaga keseimbangan hidup dalam menjalankan rumah tangga yang baik.

Undang-Undang Nomor 16 tahun 2019 tentang perubahan atas UndangUndang Nomor 1 Tahun 1974 Tentang Perkawinan tersebut memberikan peluang untuk terjadinya perkawinan di bawah umur, sebagaimana yang tercantum dalam Pasal 7 ayat 2 mengatur bahwa dalam penyimpangan terhadap Pasal 7 ayat 1 Undang-Undang Nomor 16 tahun 2019 tentang perubahan atas Undang-Undang Nomor 1 tahun 1974 Tentang Perkawinan dapat meminta dispensasi perkawinan ke Pengadilan Agama setempat. Dispensasi perkawinan merupakan dispensasi yang diberikan pengadilan agama kepada kedua mempelai bagi yang belum cukup umur untuk melangsungkan perkawinan bagi pria belum mencapai 19 (sembilan belas) tahun dan wanita belum mencapai 16 (enam belas) tahun.

Prinsip kematangan calon mempelai dimaksudkan bahwa calon suami istri harus telah matang jasmani dan rohani

${ }^{3}$ Abd.Shomad, hukum islam: Penormaan Prinsip Syariah dalam Hukum Indonesia, 273-274. 
untuk melangsungkan perkawinan, agar supaya dapat memenuhi tujuan luhur dari perkawinan dan mendapat keturunan yang baik dan sehat. Oleh karena itu harus dicegah adanya perkawinan di bawah umur. Di samping itu perkawinan mempunyai hubungan erat dengan masalah kependudukan. Ternyata bahwa batas umur yang lebih rendah bagi wanita untuk kawin mengakibatkan laju kelahiran yang lebih tinggi. Oleh karena itu ditentukan batas umur untuk kawin yaitu 19 tahun bagi pria dan 16 tahun bagi wanita. Bahkan dianjurkan perkawinan itu dilakukan pada usia sekitar 25 tahun bagi pria dan 20 tahun bagi wanita. Namun demikian dalam keadaaan yang sangat memaksa (darurat), perkawinan di bawah umur minimum sebagaimana ditentukan dalam UndangUndang Perkawinan tersebut dimungkinkan, setelah memperoleh dispensasi dari Pengadilan atas permintaan orang tua. ${ }^{4}$

Jika kedua calon suami isteri tersebut sama beragama Islam, maka keduanya dapat mengajukan permohonan bahkan boleh sekaligus hanya dalam surat permohonan untuk mendapatkan perkawinan ke Pengadilan Agama. Jika calon suami isteri non muslim dan calon suami beragama Islam, maka istri mengajukan permohonan ke Pengadilan Negeri, sedangkan calon suami mengajukan permohonan ke Pengadilan Agama, tidak peduli apapun agama orang tua mereka.

Di Indonesia, batas usia perkawinan yang ditetapkan adalah 19 tahun bagi lakilaki dan 19 tahun bagi perempuan. Hanya saja, batasan ini dapat disimpangi dengan mengajukan dispensasi perkawinan ke Pengadilan Agama. Tidak adanya kriteria atau indikator standar dalam UndangUndang Perkawinan tersebut membuka peluang bagi majelis hakim untuk memberikan putusan berdasarkan inisiatifnya sendiri, yang cenderung

\footnotetext{
${ }^{4}$ Mardani Hukum Perkawinan Islam di Dunia Islam Modern, Graha Ilmu,..21.
}

mengacu pada teks-teks fiqih. Implikasinya, sebagian besar permohonan dispensasi perkawinan slalu dikabulkan, sehingga faktor penyebab perkawinan di bawah umur. Dalam Hukum Islam, memang tidak spesifik tidak membahas usia perkawinan . Al-Qur'an hanya menetapkan dengan tanda-tanda dan isyarat kepada kaum muslimin untuk menentukan batas umur yang ideal, yang sesuai dengan syarat dan tanda-tanda yang telah ditentukan, serta diselesaikan dengan dimana hukum itu akan diperundangkan. Demikian juga dalam hukum adat, tidak ada ketentuan batas umur untuk melakukan pernikahan. "Biasanya kedewasaan seseorang dalam hukum adat diukur dengan tanda-tanda bagian tubuh, apabila anak wanita sudah haid (datang bulan), buah dada sudah menonjol berarti sudah dewasa. Bagi laki-laki ukurannya dilihat dari perubahan suara, postur tubuh dan sudah mengeluarkan mani atau sudah mempunyai nafsu seks. ${ }^{5}$

Adanya pengaturan ini, secara otomatis dapat memberikan peluang bagi masyarakat untuk dapat melangsungkan perkawinan di bawah umur. Permasalahan ini terjadi karena berbagai latar belakang yang menyebabkan terjadinya perkawinan tersebut. Ada kalangan yang memang mengharapkan atau menginginkan untuk melakukan pekawinan di usia muda dan ada yang melakukan perkawinan itu harus dilakukan sebelum seseorang mencapai umur yang sesuai dngan ketentuan yang ditetapkan Undang-Undang Nomor 16 tahun 2019 tentang perubahan atas Undang-Undang Nomor 1 Tahun 1974 Tentang Perkawinan dengan petimbangan apabila perkawinan tersebut tidak dilakukan, maka akan menimbulkan akibat yang negatif atau merugikan baik kedua belah pihak atau bagi orang lain yang bersangkutan dalam hal untuk menjaga

\footnotetext{
${ }^{5}$ Safrin Salam, Dispensasi perkawinan di Bawah Umur:Persepektif Hukum Adat, Hukum Negara dan Hukum Islam, Artikel dalam "Jurnal Pagaruyuang", Vol. 1 No. 1 Tahun 2014, 112
} 
nama baik. Memang perkawinan itu harus segera dilaksanakan dengan berbagai alasan seperti mempelai wanita hamil duluan, atau pria dan wanita telah sering bersama-sama (berpacaran). Oleh sebab itu, apabila memperoleh keturunan dari perkawinan tersebut, sehingga dalam pelaksanaannya perlu mendapatkan dukungan atau dispensasi dari berbagai pihak termasuk Pengadilan Agama. ${ }^{6}$

Permohonan dispensasi perkawinan yang diajukan oleh pemohon (orang tua anak) yang umumnya belum mncapai batas minimal diperbolehkan melangsungkan perkawinan, yang nyata-nyata anak tersebut masih di bawah umur. Dalam perkembangannya, permohonan dispensasi perkawinan oleh orang tua ke Pengadilan Agama yang dinilai hanya untuk menutupi kesalahan pergaulan anak yang kemudian solusinya adalah "menikah".

Berdasarkan latar belakang di atas, maka penulis tertarik untukmembuat judul yaitu,Implementasi

Dispensasi

Perkawinan Di Bawah Umur Berdasarkan Undang-Undang Nomor 16 tahun 2019 tentang perubahan atas Undang-Undang Nomor 1 Tahun 1974 Tentang Perkawinan (Studi Kasus di Kabupaten Kuningan).

\section{Rumusan Masalah dan Batasan Masalah}

\section{Rumusan Masalah}

Berdasarkan latar belakang yang telah dipaparkan di atas, secara umum yang akan dibahas dalam proposal ini adalah sebagai berikut :

1. Bagaimana pengaturan dispensasi perkawinan di bawah umur Berdasarkan Undang-Undang Nomor 16 tahun 2019 tentang perubahan atas Undang-Undang Nomor 1 Tahun 1974 Tentang Perkawinan?

2. Bagaimana Implementasi dispensasi perkawinan di bawah umur di

\footnotetext{
${ }^{6}$ Mardani Hukum Perkawinan Islam di Dunia Islam Modern, G..3
}

Pengadilan Agama Kabupaten
Kuningan?

\section{Batasan Masalah}

Penelitian dengan judul "Implementasi Dispensasi Perkawinan Di Bawah Umur Berdasarkan Pasal 7 Ayat 2 UndangUndang Nomor 16 tahun 2019 tentang perubahan atas Undang-Undang Nomor 1 Tahun 1974 Tentang Perkawinan (Studi Pengadilan Agama Kabupaten Kuningan)" ini terbatas pada kajian terhadap latar belakang implementasi dispensasi perkawinan, proses pemberian dispensasi perkawinan di bawah umur di Pengadilan Agama Kabupaten Kuningan pada kelas I A.

\section{Metode Penelitian}

Metode penelitian adalah prosedur atau cara untuk memperoleh pengetahuan yang benar atau kebenaran melalui langkah-langkah yang sistematis. Dalam uraian ini dimuat dengan jelas Metode yang digunakan peneliti. Pengguna metode berimplikasi pada teknik pengumpulan dan analisis data serta kesimpulan yang diambil. Penelitian ini menggunakan metode penelitian deskriptif-analitik, penelitian deskriptif-analitik yaitu dengan berusaha mengumpulkan data dan memaparkan tentang implementasi dispensasi perkawinan di bawah umur. ${ }^{7}$

\section{Pembahasan}

\subsection{Pengaturan Dispensasi \\ Perkawinan di Bawah Umur Berdasarkan Undang-Undang Nomor 1 Tahun 1974 Tentang Perkawinan.}

Suatu perkawinan adalah sah apabila dilakukan berdasarkan ketentuan agama dan kepercayaan masing-masing sebagaimana disebutkan dalam Pasal 2 Ayat (1) Undang-Undang Nomor 16 tahun 2019 tentang perubahan atas UndangUndang Nomor 1 tahun 1974 Tentang Perkawinan. Selain itu, tiap-tiap

\footnotetext{
${ }^{7}$ Fakultas Hukum Universitas Kuningan, Buku Panduan Penulisan Hukum, Kuningan, 2016... 13
} 
perkawinan tersebut harus dicatat menurut peraturan perundang-undang yang berlaku.

Dispensasi nikah diperlukan bagi calon pria yang belum berumur 19 tahun dan calon pengantin wanita yang belum berumur 19 tahun. Sebagaimana ditentukan dalam Undang-undang, perkawinan hanya diizinkan jika pihak pria mencapai 19 tahun dan pihak wanita sudah mencapai 19 tahun Undang-Undang Nomor 16 tahun 2019 tentang perubahan atas UndangUndang Nomor 1 Tahun 1974 Pasal 7 Ayat (1). Dalam hal penyimpangan terhadap ayat (1) pasal ini dapat meminta dispensasi kepada pengadilan atau pejabat lain, yang ditunjuk oleh kedua orang tuanpihak pria maupun pihak wanita Undang-Undang Nomor 16 tahun 2019 tentang perubahan atas Undang-Undang Nomor 1 Tahun 1974 Pasal 7 Ayat (2).

Syarat-syarat perkawinan sebagaimana yang diatur dalam Undang-Undang Pekawinan adalah:

1. Perkawinan harus didasarkan atas persetujuan kedua calon mempelai;

2. Telah memenuhi batas usia minimal untuk melakukan perkawinan, yaitu 19 tahun bagi laki-laki dan 19 tahun bagi perempuan; dan

3. Mendapat izin kedua orang tua, untuk anak yang belum mencapai usia 21 tahun. Apabila salah satu orang tua meninggal dunia atau dalam keadaan tidak mampu untuk menyatakan kehendaknya, maka izin cukup diperoleh dari orang tua yang hidup atau orang tua yang mampu menyatakan kehendaknya, dalam hal kedua orang tua meninggal dunia atau dalam keadaan tidak mampu menyatakan kehendaknya, maka izin diperoleh dari wali, orang yang memelihara atau keluarga yang mempunyai hubungan darrah dalam garis keturunan lurus keatas selama mereka masih hidup dan dalam keadaan dapat menyatakan kehendaknya.

Untuk perkawinan antar umat Islam, diatur dalam Kompilasi Hukum Islam. Untuk kemaslahatan keluarga dan rumah tangga perkawinan hanya boleh dilakukan calon mempelai yang sudah mencapai umur yang ditetapkan dalam Pasal 7 Undang-Undang Nomor 16 tahun 2019 tentang perubahan atas Undang-Undang Nomor 1 Tahun 1974 yakni calon suami sekurang-kurangnya 19 tahun dan calon istri sekurang-kurangnya berumur 19 tahun , Pasal 15 Ayat (1).Dalam perkawinan antar umat Islam harus memenuhi rukun dan syarat perkawinan. Rukun perkawinan merupakan hal-hal yaang harus ada dalam perkawinan, yang terdirri dari calon suami, calon isteri, wali nikah, dua orang saksi,serta ijab dan qabul. Mengenai batas usia minimum dan persetujuan kedua calon mempelai sebagaimana diatur dalam Undang-Undang Perkawinan dan Kompilasi Hukum Islam.

Aturan Dispensasi Perkawinan sebagaimana dijelaskan di atas, terdapat batas usia minimal bagi kedua calon mempelai. Namun, terdapat pengecualian sebagaimana diatur dalam Pasal 7 UndangUndang Perkawinan :

(1). Perkawinan hanya dizinkan jika pihak pria sudah mencapai umur 19 (sembilan belas) tahun dan pihak wanita 19 (sembilan belas) tahun;

(2). Dalam hal penyimpangan terhadap ayat (1) pasal ini dapat meminta dispensasi kepada pengadilan atau pejabat lain yang ditunjuk oleh kedua orang tua pihak pria maupun pihak wanita; dan

(3). Ketentuan-ketentuan mengenai keadaan salah seorang atau kedua orang tua tersebut dalam pasal 6 ayat (3) dan (4) Undang-undang ini berlaku, berlaku juga dalam hal permintaan dispensasi tersebut ayat (2) 
pasal ini dengan tidak mengurangi yang dimaksud dala pasal 6 ayat (6).

Dalam pelaksaanaan teknis ketentuan Undang-undang, dalam Peraturan Menteri Agama Nomor 3 Tahun 1975 ditentukan, dispensasi pengadilan agama adalah penetapan yang berupa dispensasi untuk calon suami yang belum mencapai umur 19 tahun dan atau calon istri yang belum mencapai umur 19 tahun yang dikeluarkan oleh Pengadilan Agama (Peraturan Menteri Agama Nomor 3 Tahun 1975 Pasal 1 (2) sub g) Apabila seorang calon suami belum mencapai umur 19 tahun dan atau calon istri belum mencapai 19 tahun hendak melangsungkan pernikahan harus mendapat dispensasi dari Pengadilan Agama (Peraturan Menteri Agama Nomor 3 Tahun 1975 Pasal 13 Ayat (1).

Bagi umat Islam, dispensasi kawin diperoleh berdasarkan penetapan Pengadilan Agama sebagaimana diatur dalam Pasal 13 Peraturan Menteri Agama Nomor 3 Tahun 1975 tentang Kewajiban Pegawai Pencatat Nikah dan Tata Kerja Pengadilan Agama dalam Melaksanakan Peraturan Perundng-Undangan Perkawinan Bagi yang Beragama Islam :

1. Apabila calon suami belum mencapai umur 19 tahun dan calon isteri belum mencapai 19 tahun hendak melangsungkan pernikahan harus mendapat dispensasi dari Pengadilan Agama;

2. Permohonan dispensasi nikah bagi mereka tersebut pada ayat (1) pasal ini, diajukan oleh kedua orang tua pria maupun wanita kepada Pengadilan agama yang mewilayahi tempat tinggalnya;

3. Pengadilan Agama setelah memeriksa dalam persidangan, dan berkeyakinan bahwa terdapat hal-hal yang memungkinkan untuk memberikan dispensasi tersebut, maka Pengadilan Agama memberikan dispensasi nikah dengan satu penetapan; dan

4. Salinan penetapan dibuat dan diberikan kepada pemohon untuk memenuhi persyaratan melangsungkan pernikahan.

Mengenaiperyaratan administratif permohonan dispensasi menikah di pengadilan, sepanjang penelusuran tidak terdapat persyaratan administratif yang baku dalam perundang-undangan.

Dari ketentuan di atas, bahwa dalam permohonan dispensasi kawin, pengadilan mengeluarkan penetapan, bukan putusan. Hal ini karena dispensasi kawin dilakukan dengan mengajukan permohonan, bukan gugatan. Penetapan dispensasi kawin yang berakhir NO (Niet On vankelijk Verklaard). , dalam penetapan juga dimungkinkan untuk ditetapkan NO oleh hakim. Dalam penetapan tersebut, hakim menetapkan permohonan dispensasi kawin yang diajukan pemohon (orang tua anak) tidak cukup alasan dikarenakan anak pemohon masih ingin bersekolah sehingga permohonan pemohon kabur (obscuur libel), karenanya tidak dapat diterima (Niet On vankelijk Verklaard). Dapat dikatakan alasan hakim menetapkan penetapan NO (Niet On vankelijk Verklaard). dalam alasan perohonan kabur (obscuur libel), cukup alasan bagi hakim untuk menyatakan bahwa permohonan dispensasi mmenikah tidak dapat diterima oleh karena alasan permohonan yang kabur atau tidak cukup alasan.

Dalam Teori KeadilanJohn Rawls menegaskan pandangannya terhadap keadilan bahwa program penegakan keadilan yang berdimensi kerakyatan haruslah memperhatikan dua prinsip keadilan, yaitu: Pertama, memberi hak kesempatan yang sama atas kebebasan dasar yang paling seluas luasnya kebebasan yang sama bagi setiap orang. Kedua, mampu mengatur kembali kesenjangan sosial ekonomi yang terjadi sehingga dapat memberi keuntungan yang bersifat timbal balik. 
Dalam penjelasannya yang pertamadengan pemberian dispensasi perkawinan di bawah umur maka memberikan kembali kesempatan haknya kepada pemohon dan calon mempelai yang akan melakukan perkawinan. Dengan diberikannya dispensasi kawin oleh Pengadilan Agama, maka keabsahan hubungan dan status perkawinan mereka sah dihadapan hukum dan di mata masyarakat tetapi lain hal yang melakukan perkawinan tetapi sudah hamil terlebih dahulu. Apabila permohonan dispensasi kawin tidak dikabulkan, maka di takutkan terjadi dampak yang luar biasa. Untuk menghindari hal-hal tersebut, maka hakim atau pejbat yang berwenang yang di tunjuk dari pihak pemohon harus lebih mempertimbangkan kemanfaatan hukum dalam mengabulkan permohonan dispensasi usia perkawinan.

Adapun faktor yang menjadi dasar pertimbangan hakim dalam mengabulkan permohonan dispensasi perkawinan, faktor yang menjadi dasar pertimbangan hakim dalam mengabulkan permohonan dispensasi usia perkawinan yaitu hakim tidak terikat pada hukum positif. Hakim diberi kesempatan untuk melakukan penemuan hukum dengan pertimbangan bahwa apabila undang-udang menetapkan hal-hal tertentu untuk peristiwa tertentu, berarti perturan itu terbatas pada peristiwa tertentu.hakim tidak hanya perpacu pada undang-undang karena apabila hakim menggunakan metodologi dalam pengkajian hukum Islam (fiiqih) mengenai permohonan usia kawin, perlu di pertimbangkan maslahat mursalah (metode ijtihad dalam hukum Islam yang berdasarkan kemaslahatan hukum).

Hakim mengedepankan konsep maslahat mursalahyaitu pertimbangan kebaikan dan menolak kerusakan dalam masyarakat serta uapaya mencegah kemudharatan. Maslahat mursalah itu adalah maslahah yang hakiki dan bersifat umum, dalam arti yang dikabulkanya dispensasi usia perkawinan terhadap anak yang belum cukup umur untuk melakukan perkawinan dapat diterima dengan akal sehat bahwa ia betul-betul mendatangkan manfaat bagi kedua calon mempelai serta keluarga masing-masing mempelai dan menghilangkan mudharat dari perbuatanperbuatan dosa yang dilakukan pasangan muda-mudi diluar perkawinan.

Adapun faktor penyebab lain yang menyebabkan di kabulkannya dispensasi kawin di pengadilan Agama Kuningan, dalam pasal 7 ayat (2) disebutkan dalam penyimpangan terhadap ketentuan ayat (1) mengenai batas usia untuk menikah, dapat meminta dispensasi kepada Pengadilan Agama atau pejabat lain yang ditunjuk oleh kedua orang tua pihak laki-laki ataupun perempuan. Jadi, berddasarkan pasal 7 ayat (2) Undang-Undang Nomor 16 tahun 2019 tentang perubahan atas Undang-Undang Nomor 1 Tahun 1974 tentang perkawinan, hakim diberi kewenangan untuk mengabulkan permohonan dispensasi di bawah umur perkawinan. Dari hasil penelitian yang dilakukan, ditemukan beberapa faktor yang menjadi penyebab diajukannya dispensasi perkawinan. Dalam hal ini pihak Pengadilan Agama Kuningan menyebutkan maraknya dispensasi perkawinan adalah karena faktor hamil diluar nikah, faktor ekonomi, faktor pendidikan, pacaran sudah terlalu dekat sehingga menimbulkan rasa kekhawatiran, dan sudah ada kemauan dari kedua pihak untuk menikah.

Penekanan pada asas kepastian hukum lebih bernuansa pada terciptanya keteraturan dan ketertiban dalam masyarakat. Penekanan pada asas keadilan, berarti hakim harus mempertimbangkan hukum yang hidup dalam mayarakat, yang terdiri dari kebiasaan dan ketentuan hukum yang tidak tertulis. Dalam hal ini harus dibedakan mana rasa keadilan menurut individu, kelompok dan masyarakat. Selain itu, keadilan dari suatu masyarakat tertentu, belum tentu sama dengan rasa keadilan masyarakat tertentuyang lainnya. Jadi dalam pertimbangan putusanya, hakim harus menggambarkan hal itu semua, manakala hakim memilih atas keadilan, 
misalnya, sebagai dasar untuk menjatuhkan putusan. Penekanan pada asas kemanfaatan lebih bernuansa kepada segi ekonomi, dengan dasar pemikiran bahwa hukum itu ada untuk manusia, sehingga tujuan hukum itu harus berguna bagi masyarakat banyak. Orang tua mengajukan permohonan dispensasi ke Pengadilan Agama dikabulkan oleh hakim karena dianggap lebih besar maanfaatnya dari pada tidak di kabulkan.

Kedua,mampu mengatur kembali kesenjangan sosial ekonomi yang terjadi sehingga dapat memberi keuntungan yang bersifat timbal balik. Karena kembali lagi pada tujuan awal menikah yaitu untuk menjadikan keluarga yang sakinah, mawadah, dan warahmah. Hingga hidup aman, damai, sejahtera dan bahagia , maka dari itu adanya dispensasi kawin untuk memperbaiki kehidupan dan kesenjangan ekonomi dan terhindar dari mudarat yang tambah besar.

Teori keadilan sangat mendukung sekali dengan adanya pemberian dispensasi perkawinan di bawah umur karena dapat bermanfaat yang bersifat ttimbal balik, sehingga mengurangi terjadinya kemudarathan yang lebih besar kepada pihak pemohon untuk melangsungkan perkawinan meskipun umurnya bertentangan denga ketentuan UndangUndang Nomor 16 tahun 2019 tentang perubahan atas Undang-Undang Nomor 1 Tahun 1974 Tentang Perkawinan Pasal 7 Ayat (1), tetapi dispensasi tetap bisa di langsungan dengan adanya ketentuan dlam Pasal 7 Ayat (2) tentang pemberian dispensasi di bawah umur.

\subsection{Implementasi Dispensasi} perkawinan di Bawah Umur di Pengadilan Agama Kuningan.

"Dispensasi Perkawinan adalah pengecualian dari aturan karena adanya pertimbangan yang khusus pembebasan dari suatu kewajiban atau larangan, dispensasi yang diberikan Pengadilan Agama kepada calon mempelai yang belum cukup umur untuk melangsungkan perkawinan, bagi laki-laki belum mencapai
19 (Sembilan belas) tahun dan perempuan belum mencapai 19 (sembilan belas) tahun. Dispensasi perkawinan terjadi karena adanya suatu hal-hal tertentu yang menjadi alasan dilangsungkannya perkawinan di bawah umur dengan ketentuan-ketentuan yang telah diatur". 8

\section{Syarat-syarat melakukan dispensasi perkawinan :}

1. Menyerahkan Surat penolakan dari KUA (Kantor Urusan Agama) yang diserahkan kepada Pengadilan Agama setempat karena pihak mempelai pria dan mempelai wanita belum mencapai umur yang di tetapkan di Undangundang Perkawinan;

1. Menyerahkan Surat Permohonan Dispensasi Perkawinan kepada Pengadilan Agama setempat;

2. Foto Copy KTP pemohon Dispensasi Perkawinan;

3. Menyerahkan Foto Copy Akte Kelahiran anak yang belum cukup umur;

4. Menyerahkan surat keterangan dari dokter (hamil atau tidak) bagi pihak perempuannya jika hamil diluar nikah; dan

5. Lain-lain akan ditentukan Hakim dalam persidangan.

2. Proses pengajuan, dan penyelesaian permohonan dispensasi perkawinan harus memedomani hal-hal sebagai berikut :

1. Permohonan dispensasi perkawinan dapat dilakukan oleh kedua calon mempelai atau orang tua yang anaknya yang masih belum cukup umur untuk melangsungkan perkawinan ke Pengadilan Agama dalam wilayah hukum pemohon bertempat tinggal, Pengadilan Agama setelah memeriksa dalam persidangan dan berkeyakinan bahwa terdapat hal-hal yang memungkinkan

8 Asadurrahman, Hakim di Pengadilan Agama Kuningan, wawancara tanggal 29 Mei 2019. 
untuk memberikan dispensasi tersebut, maka Pengadilan Agama memberikan dispensasi nikah dengan suatu penetapan. Dalam hal permohonan dispensasi perkawinan ini harus dari orang tua atau wali calon pengantin dan permohonan dispensasi nikah harus dilengkapi alasan dan kepentingan yang jelas dan konkrit; dan

2. Sebelum adanya permohonan ke Pengadilan Agama pemohon mengajukan terlebih dahulu ke KUA (Kantor Urusan Agama) kebanyakan ditolak dari kasus tersebut karena hamil diluar perkawinan adapun alasan yang lain karena kedua calon mempelai belum cukup umur untuk melangsungkan perkawinan, sehingga Kantor Urusan Agama mengeluarkan Surat Penolakan dan Surat tidak memenuhi syarat karena tidak memenuhi syarat maka perkawinan tersebut ditolak, tetapi sekarang Kantor Urusan Agama hanya mengeluarkan satu surat tidak memenuhi syarat sehingga perkawinan tersebut ditolak. Setelah adanya penolakan dari Kantor Urusan Agama karena tidak memenuhi syarat maka pemohon mengajukan dispensasi perkawinan ke Pengadilan Agama, adapun yang mengajukannya bapaknya,walinya atau orang tua dari calon yang belum mencapai umur.Dan proses penyelesain perkara permohonan dispensasi kawin di Pengadilan Agama, ketua Majelis Hakim seteelah menerima berkas perkara, bersama-sama hakim anggotanya mempelajari berkas perkara. Kemudian menetapkan hari, dan tanggal serta jam kapan perkara itu disidangkan serta memerintahkan agar para pihak dipanggil untuk menghadap pada hari, tanggal, dan jam yang telah ditentukan.kepada para pihak diberitahukan pula bahwa mereka dapat memeprsiapkan bukti- bukti yang diajukan dalam persidangan.

Setelah persidangan di buka dan dinyatakan terbuka untuk umumoleh Ketua Majelis, maka para pihak berperkara dipanggil ke ruang persidangan. Kemudian ketu a majelis membacakan surat permohonan pemohon yang telah didaftarkan di kepaniteraan pengadilan agama. Selanjutnya ketua majelis memulai pemeriksaan dngan pertanyaan yang diajukan kepada pemohon dan calon anak pemohon secara bergantian. Kemudian Ketua Majelis melanjutkan pemeriksaan bukti surat, daan pemohon menyerahkan bukti surat :

1. Foto copy surat kelahiran atas nama anak pemohon yang dikeluarkan oleh kepala desa atau kelurahan.

2. Surat pemberitahuan penolakan melangsungkan pernikahan Model N-9 yang dikeluarkan oleh Kantor Urusan Agama.

Selanjutnya Ketua Majelis menyatakan sidang di skros untuk musyawarah. Pemohon, anak pemohon dan calon anak pemohon di perintahkan keluar dari ruang persidangan. Setelah musyawarah selesai, skross dicabut dan pemohon dipanggil kembali masuk ke ruang persidangan, kemudian dibacakan penetapan yang amarnya sebagai berikut mengaddili :

1. Mengabulkan permohonan pemohon;

2. Menetapkan memberi dispensasi kepada pemohon untuk menikahkan anaknya bernama $\mathrm{xx}$ dengan $\mathrm{xxx}$; dan

3. Membebankan biaya perkara sebesar Rp.....(...) kepada pemohon.

4. Setelah membacakan penetapannya, Ketua Majelis menyatakan sidag ditutup. Jika pemohon tidak puas dengan penetapan hakim, pemohon langsung bisa kasasi, bukan banding.

Adapun permohonan dispensasi dikabulkan, ditolak, dan dicabut karena 
permasalahan yang diajukan ke Pengadilan Agama semuanya disidangkan terlebih dahulu terutama dispensasi perkawinan untuk bahan pertimbangan Hakim dalam mengambil keputusan yang akan dilaksanakannya perkawinan di bawah umur. Dispensasi perkawinan dikabulkan dan yang dijadikan bahan pertimbangannya untuk dilakukan atau dilaksanakannya perkawinan di bawah umur karena telah terbukti dia sudah hamil diluar nikah ataupun karena keduanya sudah sangat dekat sehingga ada kekhawatiran dari orang tuanya karena takut terjadi yang tidak diinginkan oleh pihak keluarganya sehingga pertimbangan-pertimbangan itu yang dapat di kabulkan.

$$
\text { Implementasi Dispensasi }
$$

Perkawinan pada Pengadilan Agama Kuningan sama dengan prosedur berperkara pada umumnya. Pemohonan Dispensasi perkawinan diajukan oleh orang tua pria maupun wanita kepada Pengadilan Agama yang mewilayahi tempat tinggalnya. Kemudian pemohon menyerahkan syarat-syarat dispensasi ke Pengadilan Agama yang telah di tetapkan.

Meskipun demikian penyimpangan terhadap batasan usia tersebut dapat terjadi ketika ada dispensasi yang diberikan oleh Pengadilan ataupun pejabat lain yang ditunjuk. Permohonan dispensasi perkawinan ini dapat diajukan oleh kedua orang tua dari pihak pria maupun pihak wanita. Didalam Pasal 6 ayat (1) dan (2) undang-undang perkawinan juga mengatur bahwa perkawinan harus didasarkan atas persetujuan kedua calon mempelai dan bagi mempelai yang belum berusia 21 tahun harus ada izin dari orang tua.

Perkawinan akan semakin jelas dan sangat penting eksistensinya ketika dilihat dari aspek hukum. Perkawinan di pandang sebagai perbuatan hukum (rechtsfeit) yakni perbuatan dan tingkah laku subjek hukum yang membawa akibat hukum, karena hukum mempunyai kekuatan hukum. Perkawinan disini tidak hanya dilihat sebagai sebuah ibadah semata, akan tetapi perkawinan juga merupakan perbuatan hukum, disinilah arti pertingnya perkwinan diatur dalam sebuah peraturan perundangan untuk melindungi masyarakat.

3. Presentase Pelaku Dispensasi

Perkawinan di Bawah Umur di

Pengadilan Agama Kuningan Pada

Tahun 2017-2019 dan Gambaran Umum

Pengadilan Agama Kuningan

Presentase Pelaku Dispensasi

Perkawinan di Bawah Umur yang terjadi di Tahun 2017-2019

\begin{tabular}{|c|c|c|c|c|c|c|c|c|}
\hline № & Jenis Perkara & Bayabrya Perkara & Dicabut & Dikabulkan & Ditolak & Dizuzurkan & $\begin{array}{l}\text { Tidak } \\
\text { Diterina }\end{array}$ & $\begin{array}{l}\text { Dicoret dari } \\
\text { Register }\end{array}$ \\
\hline 1 & $\begin{array}{l}\text { Dispenssí Kawin } \\
\text { Tahun } 2017\end{array}$ & 54 & 9 & 40 & . & . & 3 & 2 \\
\hline \multirow[t]{2}{*}{2} & $\begin{array}{l}\text { Dispenssí Kawin } \\
\text { Tahun } 2019\end{array}$ & 51 & 5 & 38 & . & 2 & 4 & 2 \\
\hline & $\begin{array}{l}\text { Jumlah } \\
\text { Keselunhan }\end{array}$ & 105 & 14 & 78 & - & 2 & 7 & 4 \\
\hline
\end{tabular}

Sumber : Pengadilan Agama Kuningan

KETERANGAN

Dicabut :Tidak jadi mengajukan dispensasi perkawinan

Dikabulkan

Memenuhi

Persyaratan

Ditolak

Karena

tidak terbukti dibawah umur

Tidak diterima

Tidak

sesuai dengan hukum

Digugurkan : Tidak datang saat persidangan

Dicoret dari Register: Pernah datang kepengadilan, tetapi tidak ada tindaklanjuti meskipun sudah di panggil beberapa kali.

Dari tabel presentase pelaku dispensasi perkawinan di bawah umur yang terjadi di tahun 2017-2019 di atas menerangkan bahwa :

Dispensasi perkawinan dikabulkan jika dalam persidangan dapat membuktikan bahwa kedua calon, atau salah satu dari calon terseebut belum cukup umur untuk melaksanakan perkawinan dan calom 
mempelai wanitanya telah hamil diluar nikah. Permohonan dispensasi perkawinan jika ditolak di dalam persidangan apa yang didalilkan tidak terbukti dan ketika diminta untuk mengumpulkan semua persyaratan yang di minta dari Pengadilan Agama tidak menyerahkan juga. Permohonan dispensasi tidak diterima karena perkawinan tersebut tidak sesuai dengan hukum. Dan jika dispensasi perkawinan dicabut maka tidak jadi untuk mengajukan dispensasi perkawinan dan melaksanakan perkawinannya dengan cara di bawah tangan (nikah agama). Dan dispensai perkawinan digugurkantidak datang pada saat persidangan. Dan apabila dispensasi perkawinan tersebut dicoret dari register pemohon pernah datang ke pengadilan dan semenjak itu tidak pernah datang kembali ke Pengadilan meskipun sudah di panggil beberapa kali atau di tegur panjang-panjang, tetap tidak pernah datang lagi maka dinyatakaan di coret dari register karena tidak memberikan keputusan. ${ }^{9}$

\section{Kesimpulan dan Saran}

\subsection{Kesimpulan}

Berdasarkan hal-hal yang telah diuraikan pada bab-bab terdahulu, dan dari hasil penelitian yang dilakukan penyusun maka dapat ditarik kesimpulan sebagai berikut :

1. Berdasarkan ketentuan Pasal 1 Ayat 3 Undang-undang Dasar Negara Republik Indonesia Tahun 1945 menyatakan bahwa negara Indonesia adalah Negara Hukum. Yaitu bahwa dalam penyelengaraan pemerintahnya, Indonesia menjalankannya berdasarkan hukum. Yang dimana Suatu perkawinan adalah sah apabila dilakukan berdasarkan ketentuan agama dan kepercayaan masingmasing sebagaimana disebutkan dalam

\footnotetext{
${ }^{9}$ Asadurrahman, Hakim di Pengadilan Agama Kuningan, wawancara tanggal 29 Mei 2019.
}

Pasal 2 Ayat (1) Undang-Undang Nomor 16 tahun 2019 tentang perubahan atas Undang-Undang Nomor 1 tahun 1974 Tentang Perkawinan. Untuk kemaslahatan keluarga dan rumah tangga perkawinan hanya boleh dilakukan calon mempelai yang sudah mencapai umur yang ditetapkan dalam Pasal 7 Undang-Undang Nomor 16 tahun 2019 tentang perubahan atas UndangUndang Nomor 1 Tahun 1974 yakni calon suami sekurang-kurangnya 19 tahun dan calon istri sekurangkurangnya berumur 16 tahun, Pasal 15 Ayat (1) Kompilasi hukum Islam.

Perkawinan hanya diizinkan jika pihak pria mencapai 19 tahun dan pihak wanita sudah mencapai 19 tahun Undang-Undang Nomor 16 tahun 2019 tentang perubahan atas Undang-Undang Nomor 1 Tahun 1974 Pasal 7 Ayat (1). Dalam hal penyimpangan terhadap ayat (1) pasal ini dapat meminta dispensasi kepada pengadilan atau pejabat lain, yang ditunjuk oleh kedua orang tua pihak pria maupun pihak wanita Undang-Undang Nomor 16 tahun 2019 tentang perubahan atas Undang-Undang Nomor 1 Tahun 1974 Pasal 7 Ayat (2). Dispensasi ini diperoleh berdasarkan permohonan ke pengadilan dan kemudian pengadilan akan mengeluarkan penetapan. Untuk permohonan dispensasi kawin bagi umat islam, diajukan kepada Pengadilan Agama. Jadi cukup alasan bagi hakim untuk menyatakan bahwa permohonan dispensasi menikah tidak dapat diterima oleh karena alasan permohonan yang kabur. Dan adapun dispensasi perkawinan adalah pengecualian dari aturan secara umum untuk sesuatu keadaan yang bersifat khusus pembebasan dari suatu larangan atau kewajiban. Dan alasan dijadikan pertimbangan hukum dalam pemberian 
dispensasi kawin anak di bawah umur adalah wanita hamil diluar nikah, kedua belah pihak telah berzina atas dasar pacaran, anak di bawah umur yang putus sekolah (faktor pendidikan), faktor ekonomi, dan sudah ada kemauan dari kedua pihak untuk menikah. Pemberian dispensasi lebih bermanfaat dari pada tidak diberikan dispensasi atau dicegah agar tidak kawin. Dalam Teori Keadilan John Rawls menegaskan pandangannya terhadap keadilan bahwa yaitu: Pertama, memberi hak kesempatan yang sama atas kebebasan dasar yang paling seluas luasnya kebebasan yang sama bagi setiap orang. Kedua, mampu mengatur kembali kesenjangan sosial ekonomi yang terjadi sehingga dapat memberi keuntungan yang bersifat timbal balik.

2. Prosedur pelaksanaan atau pengaturan (implementasi) Dispensasi Perkawinan pada Pengadilan Agama Kuningan sama dengan prosedur berperkara pada umumnya. Pemohonan Dispensasi perkawinan diajukan oleh orang tua pria maupun wanita kepada Pengadilan Agama yang mewilayahi tempat tinggalnya. Kemudian pemohon menyerahkan syarat-syarat dispensasi ke Pengadilan Agama yang telah di tetapkan. Kemudian berkas perkara diperiksa oleh Majelis Hakim, ketua majelis memulai dengan pertanyaan pertanyaan yang diajukan kepada pemohon, anak pemohon dan calon anak pemohon secara bergantian. Kemudian Majelis Hakim melanjutkan pemeriksaan bukti surat penolakan dari Kantor Urusan Agama dan sidang di skors. Setelah musyawarah selesai, skors dicabut dan pemohon dipanggil kembali masuk keruang persidangan, kemudian dibacakan penetapannya.
Berdasarkan presentase dispensasi perkawinan dibawah umur pada tahun 2017-2019 di Pengadilan Agama Kabupaten Kuningan.

Presentase Pelaku Dispensasi Perkawinan di Bawah Umur yang terjadi di Tahun 2017-2019

\begin{tabular}{c|l|c|c|c|c|c|c|c|}
\hline No & Jenis Perkara & Bayaknya Perkara & Dicabut & Dikabulkan & Ditolak & Digugurkan & $\begin{array}{l}\text { Tidak } \\
\text { Diterima }\end{array}$ & $\begin{array}{l}\text { Dicoret dari } \\
\text { Register }\end{array}$ \\
\hline 1. & $\begin{array}{l}\text { Dispensasi Kawin } \\
\text { Tahun 2017 }\end{array}$ & 54 & 9 & 40 &. &. & 3 & 2 \\
\hline 2. & $\begin{array}{l}\text { Dispensasi Kawin } \\
\text { Tahun 2019 }\end{array}$ & 51 & 5 & 38 &. & 2 & 4 & 2 \\
\hline & $\begin{array}{l}\text { Jumlah } \\
\text { Keseluruhan }\end{array}$ & 105 & 14 & 78 &. & 2 & 7 & 4 \\
\hline
\end{tabular}

Berdasarkan pada tabel di atas banyaknya perkara dari tahun 2017-2019 yang melakukan dispensasi di Pengadilan Agama kuningan adalah 105 orang, diantaranya dispensasi yang dicabut dari perkara 14 orang ,dikabulkan 78 orang, digugurkan 2 orang, tidak diterima 7 orang dan yang dicabut dari register 4 orang.

\subsection{Saran}

Dari kesimpulan di atas, maka penyusun menyampaikan saran sebagai berikut:

1. Dengan adanya Undang-Undang Nomor 16 tahun 2019 tentang perubahan atas Undang-Undang Nomor 1 Tahun 1974 Tentang Perkawinan dan Kompilasi Hukum Islam seharusnya masyarakat patuh dan melaksanakannya dengan baik kedua Undang-Undang tersebut sesuai apa yang telah di atur di dalam kedua Undang-Undang tersebut.

2. Kepada instansi Pengadilan Agama, dalam penetapan dispensasi kawin yang kasusnya telah terjadi kehamilan di luar nikah agar memberikan penjelasan kepada pemohon terkait kejelasan nasab si anak kelak dan hendaknya orang tua memberikan bimbingan dan pendidikan kepada anaknya supaya dapat mempersiapkan 
diri dalam membina rumah tangga sejahtera, hidup bahagia.

Hendaknya Pengadilan Agama dan Kantor Urusan Agama dapat menjalin kerjasama dalam rangka mensosialisasikan peraturan perundang-ndangan perkawinan. Hal ini diharapkan dapat menjadi pengetahuan kepada masyarakat belajar tertib hukum dengan adanya sosialisasi tersebut setidaknya dapat mengurangi angka atau perkara yang melakukan permohonan dispensasi perkawinan kepada Pengadilan Agama.

\section{DAFTAR PUSTAKA}

Abd.Shomad, hukumislam: Penormaan Prinsip Syariah dalam Hukum Indonesia

Amir Syarifuddin, Hukum Perkawinan Islam di Indonesia, Prenadamedia Group, Jakarta, 2014

Amirudin dan Zainal Asikin, Pengantar Metode Penelitian Hukum, PT Raja Grafindo Persada, Jakarta, 2003

C.S.T Kansildan Christine S.T Kansil, Kamus Istilah Aneka Ilmu. Cet Ke2 (Jakarta: PT. Surya Multi Grafika, 2001)

Fajlur rahman Jurdi,Teori Negara Hukum, Setara press, Malang, 2016.

Hilman Hadikusuma, Hukum Perkawinan Indonesia, Penerbit Mandar Maju, Bandung, 2007

Kaharuddin, Nilai-nilai Filosofi Perkawinan Menurut Hukum Perkawinan Islam dan Undangundang RI Nomor 1 Tahun 1974 Tentang Perkawinan, Mitra Wacana Media, Jakarta, 2015

Lexy J Moleong, Metode Penelitian Kualitatif, Remaja Rosdakarya, Jakarta, 2010

H. Ahmad Rofiq, Hukum Perdata Islam Di Indonesia (Cet. I: Jakarta: Rajawali Pers, 2013)

Mardani, Hukum Perkawinan Islam di Dunia Islam Modern, Graha Ilmu, Yogyakarta, 2011
Mardani, Hukum Keluarga Islam di Indonesia, Kencana, 2016

Moh. Idris Ramulyo, Hukum Perkawinan, Hukum Kewarisan, Hukum Acara Peradilan Agama, dan Zakat Menurut Hukum Islam (Jakarta: Sinar Grafika, 1995)

Moh. Idris Ramulyo, Hukum Perkawinan Islam (Jakarta: Bumi Aksara, 1996)

M. Thahir Maroko, Dinamika Hukum dalam Perkawinan (Cet.I: Makasar: Alauddin University Press, 2012)

Muhammad Saleh Ridwan, Poligami dalam Hukum Islam dan Perundang-undangan di Indonesia (Cet I; Makasar: Alauddin University Press, 2011)

Noor Rahmat dan M. Chudlori Umar, Hukum Islam, Universitas Terbuka, Jakarta, 2009

Nudin Usman, Konteks Implementasi Berbasis Kurikulum, Grasindo, Jakarta, 2002

Prof. H. Hilman Hadikusuma, Hukum Perkawinan Indonesia, Mandar Maju, Bandung 1990, cetakan 2007

Ridwan H.R., Hukum Administrasi Negara, Universitas Islam Indonesia, Yogyakarta, 2007

Safrin Salam, Dispensasi perkawinan di Bawah Umur:Persepektif Hukum Adat, Hukum Negara danHuk um Islam, Artikel dalam "Jurnal Pagaruyuang", Vol. 1 No. 1Tahun 2014

Siska Lis Sulistiani, Kedudukan Hukum Anak, Refika Aditama, Bandung, 2015

Subekti, dkk, Kamus Hukum. Cet ke-4 (Jakarta: Pramita, 1979) 